\section{THOUSANDS JOIN DISCOUNT NETWORK}

Following its launch just over a year ago, Denplan is pleased to announce that the Denplan Discount Network has now accepted its 2,000th member.

Launched at the start of 2013, the Denplan Discount Network is designed to provide Denplan practices with access to the 200,000 employees currently covered by its corporate benefit products, by offering them special discounted rates.

Now with 2,000 Denplan dentists part of the network, and more joining all the time, Denplan can actively work with employers to ensure their staff are aware of all the participating dentists in their area, through a secure, easy to use website.

The website shows the participating dentists local to the employee, the level of discount offered and the employee can simply pay the practice as normal claiming back their benefit entitlement directly from Denplan.

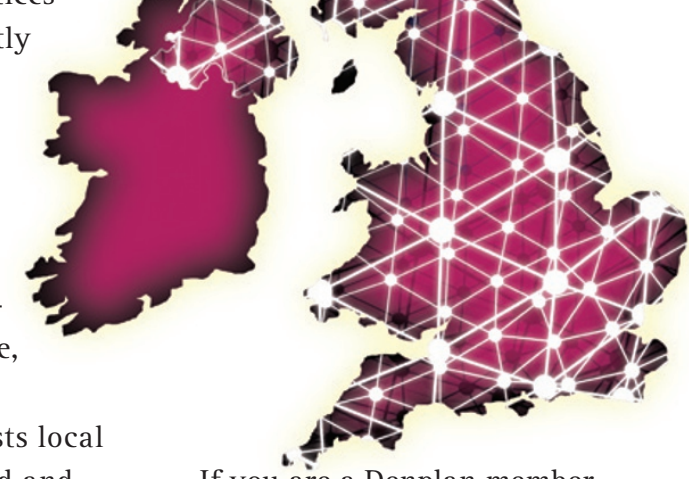

If you are a Denplan member and wish to join the Denplan Discount Network, please call 08001699962.

\title{
A SPECIAL BROADCAST ON DENTINE HYPERSENSITIVITY
}

Colgate Professional invites you to view a special learning broadcast delivered by Professor David Bartlett - Head of Prosthodontics at King's College London Dental Institute. In this broadcast, you can learn how you can further help your patients with dentine hypersensitivity. Simply view, feedback and complete CPD questions to gain one hour of verifiable CPD.

Some patients with hypersensitivity are reluctant to report sensitivity, which can make it difficult to diagnose and challenging to treat. As a result, professionals aren't always able to address the problem; subsequently, toothbrushing and flossing become painful, putting patients at an increased caries risk.

During the broadcast, Professor Bartlett provides an interesting and informative overview in which he discusses his personal experiences of dentine hypersensitivity and how his own perceptions around risk factors have evolved. The broadcast also looks at an overview, including epidemiology and aetiology, before moving to reviewing measurement methods and underlying conditions as contributing factors. Towards the end of the hour, Professor Bartlett looks at available technologies and treatment options based on the previously highlighted underlying conditions whilst sharing some interesting case studies reviewing simple, complex and resistant cases.

To view the complimentary broadcast visit www. colgateprofessional.co.uk/professionaleducation/DHSin-the-Dental-Surgery-1-hour-verifiable-CPD/video. For further information on Colgate products, visit www.colgateprofessional.co.uk.

\section{LIGHTWEIGHT AND HIGH} STRENGTH DENTURES

JUVORA, the dental innovations company specialising in the next generation of denture material, has announced Knight Dental Design as one of the first dental laboratories in the UK to become a JUVORA Certified Partner, enabling them to offer patients, dentists and other dental laboratories cuttingedge technology in partial and removable dentures.

Knight Dental Design, awarded UK Dental Laboratory of the Year 2013, uses the latest state of the art technology to complement their hand crafted cosmetic, restorative and implant solutions by offering JUVORA metal free options for high performance removable dentures and screw retained bridges.

The JUVORA Dental Disc is a high purity and high performance polymer that is digitally manufactured through CAD/ CAM equipment for optimum patient fit. Dental frameworks manufactured with the JUVORA Dental Disc are lightweight and high-strength but, compared to the metal usually used, there is also some flex which means a denture solution which acts more like the natural underlying tissue. www.juvoradental.com www.knightdentaldesign.co.uk 